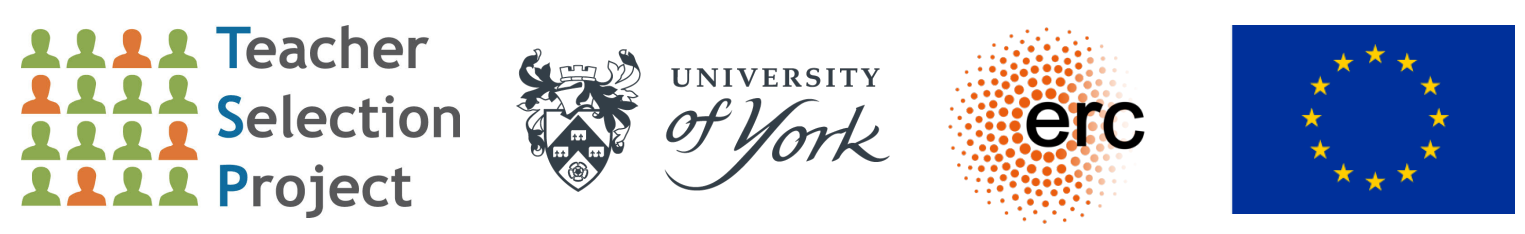

Teacher Selection Project Working Paper 03.06.20

Examining Teacher Recruitment Strategies in England

Robert M. Klassen ${ }^{1}$, Lisa Bardach ${ }^{1}$, Jade V. Rushby ${ }^{1}$, \& Tracy L. Durksen²

\author{
${ }^{1}$ University of York \\ ${ }^{2}$ University of New South Wales
}

This Working Paper reports in-progress work that is not yet peer reviewed. The purpose of the Working Paper is to stimulate discussion and to contribute to the advancement of knowledge. Please check our project website for news of recent publications. This work is supported by the European Research Council (grant \#647234 SELECTION) 
Examining Teacher Recruitment Strategies in England

\author{
Robert M. Klassen ${ }^{1}$, Lisa Bardach ${ }^{1}$, Jade V. Rushby ${ }^{1}$, \& Tracy L. Durksen ${ }^{2}$ \\ ${ }^{1}$ University of York \\ ${ }^{2}$ University of New South Wales
}

Correspondence to:

Robert Klassen

Department of Education, University of York

robert.klassen@york.ac.uk

Acknowledgements: The authors would like to gratefully acknowledge funding from the European Research Council for Consolidator grant SELECTION 647234. 


\section{Examining Teacher Recruitment Strategies in England}

\section{Abstract}

Teachers around the world are in short supply, and in England, teacher recruitment has been described as a 'crisis'. For national education systems, the goal of an effective teacher recruitment strategy is not simply to attract more applicants, but to attract high quality applicants who are well-suited to teaching and are likely to remain in the profession. The goal of this article is to examine teacher recruitment strategies in England and to propose models to better understand and to improve these strategies. We begin by reviewing personnel recruitment theories and research from education and related fields. Next, we analyse publicly available teacher recruitment strategies and messages from two key education organisations in England: the Department for Education and Teach First. We then compare teacher recruitment strategies with strategies and models developed in health professions (as presented by the National Health Service). We conclude by proposing how teacher recruitment strategies in England could be more strongly grounded in relevant theoretical and empirical work.

Keywords: teacher recruitment; teacher selection; initial teacher education; teacher retention;

\section{Introduction}

\section{The Challenges of Teacher Recruitment}

Recruiting teachers for training and employment is an ongoing global challenge that in some settings is reaching crisis levels. In 2016 the United Nations Educational, Scientific and Cultural Organization (UNESCO) reported the need to recruit almost 69 million teachers24.4 million at the primary level and 44.4 million at the secondary level - in order to ensure sustainable growth in developing countries. In England, the recruitment of initial teacher trainees has fallen below the target set by the Department for Education (DfE) in each year since 2011-2012, with growing shortfalls projected as pupil numbers increase (Foster, 2019). A census of initial teacher training (ITT) providers for 2019-2020 showed an overall ITT recruitment shortfall in England of about 11\%, or 3,500 below target, with 'acute' shortages in certain academic subjects (maths, modern foreign languages, physics, and design and technology). A shortage of high quality teachers hampers students' ability to learn, diminishes overall educational opportunities, and leads to a drain on economic resources (e.g., through provision of recruitment incentives) that could be better used elsewhere (Garcia \& Weiss, 2019). There are international exceptions to teacher shortages - Finland, for example, has many more applicants than places for ITT programmes - but in many developed and developing countries the quality of education systems is threatened by an inability to attract and recruit sufficient numbers of high quality applicants. 
Research describing the teacher recruitment landscape in England has recently been conducted by See and Gorard (2019). The authors documented the gap between ITT recruitment targets and actual number of new entrants between 2013 and 2018, and noted that teacher vacancies tripled between 2011 and 2016, with the demand for secondary teachers expected to increase over the next 20-30 years as pupil numbers grow. See and Gorard proposed several ways to address teacher shortfalls including more coherent policies accounting for teacher demand and supply, revisions to the ITT application and selection process, and robust evaluations of the cost and benefits of recruitment incentives. The DfE has identified interventions targeting teacher recruitment as an 'area of research interest' (DfE, 2018), but to date there has been little systematic work either on establishing a theoretical framework in which to understand recruitment interventions, or on developing and testing the effectiveness of interventions targeting teacher recruitment.

\section{Current Teacher Recruitment Strategies}

Many teacher recruitment strategies have followed a 2-step process: (a) identify areas (geographical areas and/or subject areas) of acute shortage, and (b) offer financial incentives for training or employment to applicants, frequently related to applicants' level of academic attainment (See \& Gorard, 2019). There are several problems associated with this approach. First, the evidence supporting the relationship between teachers' general academic abilities and teacher effectiveness is unconvincing (Bardach \& Klassen, 2020), and recruitment efforts that focus largely on incentivising potential teachers based on cognitive factors may be insufficient to ensure a pipeline of high quality teachers. Teaching demands a range of personal attributes that extend beyond cognitive (i.e., 'academic') attributes, with interpersonal or 'soft' skills playing a critical role in everyday classroom interactions that are associated with teaching effectiveness (e.g., Klassen et al., 2018). Second, offering incentives for training and for employment is expensive, and the scant research on the long-term effectiveness of teacher recruitment strategies is unpromising (Podolsky, Kini, DarlingHammond, \& Bishop, 2019).

See, Gorard, Morris, and El Soufi (2019) recently reviewed the effects of teacher recruitment policies and practices in hard-to-staff areas, and found that almost all of the recruitment policies they reviewed used financial incentives (e.g., recruitment bonuses, retention bonuses, higher salaries, remission of student loans) in attempts to boost recruitment. Although in some cases these financial incentives were initially effective in attracting teachers to work in hard-to-staff areas, the effect on retention rates lasted only as long as the financial incentives stayed in place. In spite of the high cost of using financial incentives to recruit teachers, there is little evidence that these incentives have lasting effects 
on teacher workforce numbers, with international perspectives also pointing to the long-term ineffectiveness of financial incentives.

Recruitment strategies that focus largely on providing financial incentives based on academic achievement may not provide optimal results. A recent OECD (Organisation for Economic Co-operation and Development) report on teacher recruitment policies (using evidence from the Programme for International Student Achievement [PISA] 2015) found that extrinsic financial incentives alone are not sufficient in attracting high quality teachers, and in fact, may serve to attract applicants whose career decisions are predicated on salary levels rather than on fit with the profession (OECD, 2018). People around the globe are attracted to professions by a combination of factors, including occupational status, work environment, sense of personal contributions, and the financial rewards associated with the profession (Podolsky et al., 2019). We propose that targeted recruitment campaigns are most likely to be effective if they learn from research and theory in relevant adjacent professional fields.

\section{Recruitment in other Professions: What is a 'Values Based Approach'}

Professional fields outside of education (e.g., in health care fields and policing) have focused on building recruitment strategies that focus on non-academic attributes, often conceptualised as values: principles that guide how individuals ought to behave. These personal values develop through key social interactions with family and peers, and increase in stability through adolescence and early adulthood. Parks and Guay (2009) suggest that personality (enduring dispositions) and motivation (needs and goals that induce action) are related to values (enduring beliefs), decision-making, and interpersonal relationships. Research on value congruence (i.e., fit between an individual's values and those of the organisation) shows that when value congruence is low upon entry to the organisation, workers are more likely to leave the organisation due to low commitment, frustration, and difficulties in socialisation (De Cooman et al., 2009). Implementing a values based recruitment approach requires an initial inquiry into identifying which values are (a) empirically supported, and (b) deemed central to the organisation's goals, followed by an incorporation of these values into recruitment and selection activities.

Values based recruitment strategies have been implemented in public service professions (e.g., College of Policing, 2018) and widely in health care fields (e.g., nursing, medicine, midwifery). The National Health Service (NHS) also has developed a values based recruitment strategy, with six values identified that characterise their organisation: working together for patients, respect and dignity, commitment of quality of care, compassion, improving lives, and everyone counts. These core values are incorporated into the recruitment process at the attraction stage (values are marketed to applicants), at screening (screening 
tools are developed to assess values), and subsequently at selection (use of tools, methods, and approaches to assess values). The identified values play a continuing role post-selection in the development of a values based workplace environment and in values based learning and development opportunities (NHS, 2020). Similar values based approaches to recruitment have recently been introduced in nursing and other health fields (e.g. midwifery, physiotherapy, and occupational therapy; Miller, 2015). A values based recruitment strategy is grounded in theories which build on the notion of 'fit' between organisations and occupations, and individuals interested in pursuing careers in these fields.

\section{Theoretical Frameworks Informing Recruitment}

Person-environment (and person-vocation) fit. The concept of fit between people and their environments is one of the dominant theories in psychology, and forms the basis of employee selection theory, where people are recruited and selected based on how well their values, norms, and abilities match the demands of the job (Darrow \& Behrend, 2017). Personenvironment (PE) fit has been broken down into more nuanced fit modes, including personorganisation (PO) fit (the congruence between individuals and organisational characteristics and expectations), person-job (PJ) fit (match between an individual's skills and abilities and specific demands of a specific job) and person-vocation (PV) fit, or the congruence of an individual's interests and abilities and the characteristics and requirements at the level of the occupation.

Research has shown a strong relation between PV fit and pre-employment attitudes about jobs, on-the-job attitudes (e.g., job satisfaction, commitment, subjective career success, retention), and job behaviours (including job performance and citizenship behaviours at work;e.g., Vogel \& Feldman, 2009). In a large-scale meta-analysis of studies examining predictors of applicant attraction across multiple recruitment stages, Uggerslev and colleagues (Uggerslev, Fassina, \& Kraichy, 2012) found that perceived fit was the strongest predictor (with a large effect size) of applicant attraction across multiple stages of recruitment, followed by organizational characteristics and job characteristics. The authors proposed that organisations could enhance their recruitment processes by providing applicants with feedback on the extent of their fit to an organisation, and by tailoring the recruitment process to recruit individuals with a compatible list of values and goals. In an education setting, De Coomen et al. (2009) found that attracting and selecting teachers who perceived congruence between their values and those of their schools were less likely to leave the profession.

FIT-Choice and expectancy-value theories. Watt and Richardson's FIT-Choice motivation framework represents an important theoretical and empirical base for understanding the reasons why people are attracted to a teaching career (e.g., Watt $\&$ Richardson 2007, 2008; Richardson \& Watt, 2016). Their work is based on expectancy-value 
and person-environment fit theories of motivation. Expectancy-value theory proposes that success expectancies, also referred to as competence-related beliefs (How well could I do this [now and in the future]?), interact with value judgments (Do I want this? What is gained from this?) as major determinants of motivation and life choices. The value component can be further broken down into intrinsic value (enjoyment from a task), and utility value (how useful/valuable is this to me now and in the future?). Utility values can again be broken down into personal utility (How do I personally benefit from this?) and social utility (How does this activity make a social contribution?). In terms of career decision-making, individuals will weigh multiple facets of the value of a potential career, but at the same time judge their expectancy to succeed, i.e., their competence beliefs, about a particular career. Individual motivations for making decisions about potential career paths are complex, multi-faceted, and dependent on a range of socialisation and personal factors.

Watt and Richardson found that prior socialisation experiences (social influences from family and friends, past experiences in teaching and learning) played a role in influencing decisions about entering the workforce, but also that the higher order factors of personal utility and social utility combined to influence the decisions made about pursuing a teaching career. In their FIT-Choice model, 'socialisation influences' (including prior teaching and learning experiences) interact with self-perceptions (perceived fit between abilities and teaching demands), perceived personal utility (e.g., job security), and social utility (e.g., making social contribution, shaping future of children's lives) in the decision-making process. The FIT-Choice model of teacher motivation provides a useful heuristic to understand why people enter the profession, and has been tested in a wide range of contexts (Richardson \& Watt, 2016).

Integrating FIT-Choice theory with PV Fit. In Figure 1, we show the 'simple view' of teacher recruitment in which beliefs about the social utility and personal utility of teaching influence intentions to consider a career in teaching. In this view, beliefs about making a difference in children's lives (social utility) and beliefs about the costs/benefits of a teaching career (personal utility reflected by financial incentives, pay rates, working conditions) play a direct and independent role influencing intentions to enter (and remain) in the profession. One useful framework that integrates FIT-Choice and PV fit theories is the elaboration likelihood model (Uggerslev et al., 2012), which suggests that individuals make accurate fit assessments based on (a) their motivation to make that assessment (based on how motivated they are to make the fit assessment, influenced by perceived social/personal utility features of the job), and (b) their ability to make the fit assessment (due to the amount and specificity of information about the job provided to them).

Figure 1 here 
Figure 2 here

In Figure 2, we show a moderation model of teacher recruitment in which social and personal utility beliefs are moderated by an applicant's perceptions of competency beliefs, and in particular, their perceptions of their fit with the profession. In this model, the evaluation of social and personal benefits of the profession are filtered through beliefs about the congruence between personal attributes (what Watt and Richardson term 'ability') and the attributes sought and demanded by the profession. For example, an applicant might favourably evaluate teachers' work-life balance (personal utility) and might be persuaded that teachers play an important role in influencing children's educational outcomes (social utility), but these evaluations are filtered through their perceptions of their own attributes (values and cognitive and non-cognitive competencies) and their ability to evaluate the fit (elaboration likelihood). Theoretical considerations of expectancy value and fit are important not just to understand the processes underlying career choice, but to build recruitment policies and the corresponding messages designed to attract high quality teachers into the profession.

\section{Analysing Recruitment Policies and Messages in England}

Recent teacher recruitment policies and public-facing messages in England provide insight into the principles underlying recruitment processes. We limited our focus to attraction (appeals to potential applicants to consider the profession) and recruitment (encouraging applicants to make an application), rather than retention (keeping trainees and early career teachers in the profession). Retention, obviously an important consideration in improving the teacher workforce, has been addressed in other recent studies (e.g., Geiger \& Pivovarova, 2018) and represent a different set of policy and strategy efforts.

We examined strategy documents and advertising campaigns from the DfE and Teach First, the single largest provider of teacher trainees in England, to understand how recruitment policies and messages promote social utility, personal utility, and, to a lesser extent, the fit between personal attributes (defined as competencies, values, personality, and motivation) and job demands.

To begin, we reviewed two major recruitment policy documents published in the last two years: the DfE's Teacher Recruitment and Retention Strategy was published in 2019 and Teach First's Britain at a crossroads: what will it take to provide the teachers our children need? was published in 2018 (Sundorph, 2018). The stated purpose of the DfE document is to 'set out the government's priorities for making sure a career in teaching continues to be attractive, sustainable, and rewarding' (p. 3). The recruitment-related focus of the Teach First document is on 'getting great people to the schools who need them most' (p. 3). These two education organisations released a series of public-facing recruitment advertisements based on the relevant strategy documents. 
We searched three popular social media platforms (Facebook, Twitter, and YouTube) for advertising campaigns in the last two years released by the two organisations. The DfE recently engaged an advertising agency (Havas London) to develop the Every lesson shapes a life advertising campaign, with the release of teaching-related advertisements during commercial breaks on national TV, on YouTube and other social media platforms, and in cinemas as an advertisement before featured movies. Our search resulted in two DfE videos (Every lesson shapes a life: Through the eyes of a teacher, 2019; and Every lesson shapes a life: Tuesday, 2020) and two Teach First advertisements: the video After the outcome (2019) and the advertising brochure After the outcome: A job where you're... (2019).

For comparison, we also analysed the recruitment policy document from the NHS: Values Based Recruitment Framework (NHS, 2016) which provides the framework for attraction, recruitment, selection, and development of NHS staff in England. According to the report, VBR is an evidence-based approach that sets out and then assesses values, defined as 'motivational goals that influence behaviour' (p. 17) and that affect the goals that individuals choose to pursue. In the NHS definition, values differ from personality, which is defined as 'behaviours that come more naturally, whereas values reflect effort (a choice) to behave a certain way' (p. 17). In total, we analysed seven source documents (written materials and advertising videos): six from education-related sources (i.e., from the DfE and Teach First) and one from the NHS.

\section{Analysis}

We used a document analysis approach outlined by Bowen (2009) consisting of an iterative process that coded meaning segments related to attraction and recruitment (at the phrase or sentence level) with categories based on our theory-derived framework of the research. Specifically, we used pattern recognition whereby the key search terms attract*, recruit*, and new were searched (or watched and coded in the case of videos) within documents to identify segments that explicitly or implicitly focused on attracting and recruiting new teachers. In our first pass through the data, we used a deductive (theory-based) coding strategy whereby codes were taken from FIT-Choice and Person-Vocation Fit theories (see Appendix A for coding framework), resulting in the categories administrative/system changes (recruit applicants by improving and streamlining application process and options), personal utility (recruit applicants by highlighting personal benefits), social utility (recruit applicants by showing how teaching benefits society), and $P V$ fit (recruit applicants by emphasising the fit between applicants' attributes and attributes demanded by the job). On our second pass through the data, secondary codes (reported in Appendix A) were established within each coding category (e.g., personal utility included seven secondary codes such as 'salary', 'incentives for training'). Appendix B reports a coding frequency table in which a 
description of content (i.e., description of the recruitment-focused text), location in source document, and assigned code are provided for each source document.

\section{Findings}

In Figure 3 we show the relative frequencies of recruitment messages in the seven source documents. Although each document included multiple recruitment messages, most of the documents had a primary message that took precedence over secondary messages. Only the DfE strategy document included content reflecting all four of the coding categories, while two documents - the Teach First recruitment strategy, and the DfE Every lesson shapes a life: Tuesday - included content reflecting only two of the coding categories. In the next section we examine the recruitment strategy and messages from the DfE and Teach First.

Figure 3 here

\section{DfE Recruitment Strategy and Messages}

DfE teacher recruitment strategy report. The DfE recruitment strategy report was the only source document that included all of the four code categories. The dominant code in the DfE report reflected administrative and system changes designed to attract more applicants into the recruitment system ( $59 \%$ of all codes). For example, multiple references were made to 'improving the applicant experience at every stage of the journey' (p. 32) and opening up pathways for career changers (e.g., 'supporting a Transition to Teach initiative', p. 33 ). A secondary message ( $29 \%$ of codes) focused on the personal utility of a teaching career, with statements reflecting the importance of salary levels ('To improve recruitment and retention of teachers, pay must compare favourably with similar professions', p. 9), workload ('Workload is the first topic in any discussion about the attractiveness of teaching in the UK', p. 6), and flexible work schedules ('Increased flexible working options could allow more teachers to return', p. 7). Minor references ( $6 \%$ of codes) were made to the social utility of teaching ('Our latest campaign 'Every lesson shapes a life' highlights how teachers change and shape the lives of their pupils each and every day', p. 32), and PV fit (6\% of codes; references to encouraging potential applicants to evaluate their personal fit with teaching through taster days, a virtual reality classroom, and the Teaching Internship Programme, p. 32).

DfE Every lesson shapes a life video advertisements. The DfE Every lesson shapes a life: Tuesday (2020) video portrays the daily activities of a secondary science teacher, and includes the teacher greeting pupils, interacting with pupils, and teaching lessons. The video strongly emphasised the social utility aspects of a teaching career ( $86 \%$ of all codes), especially focusing on shaping pupils' futures, making social contributions, and the satisfaction of working with children/adolescents. Additional examples of social utility include scenes of the teacher helping a troubled pupil and engaging in positive interactions 
with pupils. A secondary emphasis of the advertisement focused on the personal utility of teaching (14\% of codes), with a particular focus on the opportunity to interact with peers in a positive and collaborative manner.

The DfE Every lesson shapes a life - through the eyes of a teacher (2019) presents accounts from multiple teachers and pupils about the challenges and rewards of teaching, and includes three code categories, with social utility included most frequently (44\% of codes), followed by person-vocation fit (37\%) and personal utility (19\%). The video emphasises the social utility of teaching through references to making a positive difference to student outcomes, for example, 'I'm here to change lives'. There were multiple references to the fit between teachers' attributes and the demands of the work 'You need to be ready for anything to happen' and 'A day in the life of a teacher is very intense' (i.e., perception of job demands). Desired teacher attributes were reported from the perspective of pupils: 'She's really energetic all the time' and 'She understands us, helps us with the work, and makes it fun'. The third coding category--personal utility--included references to personal satisfaction from the job, including 'By far the most rewarding job I've ever done', 'No two days are the same' and 'I've never been bored in this job, ever'.

\section{Teach First Recruitment Strategy and Messages}

Teach First recruitment strategy. The Teach First recruitment strategy document included a majority of references to personal utility (69\% of codes), with a secondary emphasis on administrative/system changes (31\% of codes). Personal utility messages included multiple references to improving working conditions 'If teaching is to remain attractive to future generations... solutions to ensure flexible working must be found' (p. 9) and to training incentives (e.g., 'financial incentives are believed [by headteachers] to be particularly effective when recruiting teachers', p. 9). Administrative/system changes were noted in references to proposed changes to attract career changers ('with the right approach, even more people could be persuaded to change careers into teaching', p. 12).

Teach First After the outcome video and brochure. The two Teach First advertising materials - the After the outcome video and After the outcome brochure-both emphasised the personal utility of a teaching career most strongly, but with inclusion of references to social utility and person-vocation fit. The video advertisement included interviews with teachers in school contexts at various career stages, with the personal utility of a teaching career most frequently emphasised ( $46 \%$ of codes). Personal utility focused on career progression opportunities ('In terms of the career progression I've had... it's been a superb choice') and personal satisfaction ('I'm really proud of what I do every day'). Social utility codes (31\%) reflected the desire to influence the outcomes of children from disadvantaged backgrounds ('Let's give opportunities to kids who wouldn't normally have those opportunities'). Person- 
vocation fit codes $(23 \%)$ included references to the attributes needed for teaching success, and particularly how the need for 'challenge and opportunity' was met through a teaching career.

The After the outcome brochure included three messages: personal utility, social utility, and person-vocation fit. The brochure provided a description of the advantages and personal utility (55\% of codes) of teacher training with Teach First in terms of financial benefits (e.g., 'Earn a salary on day one in the classroom', 'Pursue a master's qualification at a reduced cost') but also in terms of support during the programme ('Receive dedicated support from three sources'). The social utility (18\%) of joining the Teach First programme was noted ('Help children in schools that need you most'). In terms of person-vocation fit ( $27 \%$ of codes), the Teach First brochure provided information about opportunities to access job previews ('Our Insights for students are a chance to gain real classroom experience' alongside references to 'our Taster Experiences... are an excellent way...to discover whether teaching is right for you'). Specific sought-after attributes were noted in the brochure (e.g., 'effective interaction', 'humility, respect, and empathy', 'resilience' etc.), allowing potential applicants to self-evaluate the fit between their own personal attributes and those sought by Teach First.

\section{NHS Values Based Recruitment Framework}

The NHS values based framework focuses on attracting, recruiting, and selecting trainees and employees on the fit between individual values and those values highlighted in the NHS Constitution. Unsurprisingly, the attraction and recruitment messages in the NHS Values Based Recruitment Framework document (2016) reflected the importance of personvocation fit ( $77 \%$ of codes), with minor consideration of administrative/system changes $(18 \%)$ and personal utility $(5 \%)$. The person-vocation fit messages were targeted at potential trainees ('All Higher Education Institutions delivering NHS funded training programmes are required to assess students for the values using the core requirements set out in this framework', p. 10) and employees ('Values should be detailed in the attraction material and specifications for the position alongside key competencies', p. 52). Some attention was paid in this document to realistic job previews ('We will provide pre-nursing care experience pilots', p. 27), with most messages focused on the match between attributes (values, competencies) of applicants and the NHS values ('there needs to be a good fit between an individual's personal values and those of the organisation [value congruence], p. 52; and, 'when an individual's values closely match those of the organisation, they report a significant increase in job satisfaction and commitment to the organisation', p. 52). Overall, the NHS document highlighted how a values based approach influences not just attraction, recruitment, and selection strategies and methods, but also influences the longer-term retention of those entering health professions. 


\section{Discussion}

Developing public-facing strategies and effective messages to attract and recruit new teachers presents an expensive challenge: a recent report (Carr, 2020) stated that the DfE spent more than $£ 37$ million on radio, $T V$, and social media advertising for teacher recruitment between 2016 and 2019. It is clear that research that develops and tests teacher recruitment interventions that are empirically sound theoretically robust is needed to address the current recruitment challenges. Our review of teacher attraction and recruitment strategies and messages delivered by the DfE and Teach First revealed some clear patterns in the messages according to document type, with recruitment strategy documents for DfE and Teach First emphasising administrative/system changes and personal utility messages, whereas the public-facing advertisements from these two organisations focused on personal utility, social utility, and to a lesser extent, the personal attributes deemed to be important for teaching, and that are associated with person-vocation fit messages.

\section{Towards a Research- and Theory-Based Approach to Teacher Recruitment}

In spite of the varied messages in strategy documents and advertising campaigns, we do not yet have a very clear idea of what works, why messages work, for whom they work, and when these messages are most effectively delivered. Research approaches that deliver targeted utility value messages (Hecht et al., 2019) to potential applicants - using a novel expectancy-value-fit approach—could prove fruitful for teacher recruitment. Current recruitment campaigns grounded in social and personal utility messages might effectively attract potential candidates, but as displayed in our model of teacher recruitment shown in Figure 2, these messages are filtered through perceptions of fit, and recruitment messages that are more detailed about the demands of the job can increase perceptions of fit (Roberson, Collins, \& Oreg, 2005).

Using realistic job previews for PV fit interventions. Teacher recruitment strategies focused on social and personal utility messages may attract potential applicants with an unrealistic view of teaching resulting in disillusionment and high attrition due to poor fit. Realistic job previews, or RJPs, provide detailed verbal, written, or video portrayals of what applicants might encounter in an occupation. Baur and colleagues (Baur, Buckley, Bagdasarov, \& Dharmasiri, 2014) showed that RJPs can provide an alternative (or complement) to traditional 'seduction' techniques of recruiting where applicants are seduced into the profession with portrayals of exclusively positive information designed to maximise the attractiveness of the profession at the expense of accuracy and accurate portrayals of the work environment.

Developing teacher recruitment strategies and messages using RJPs helps accomplish three goals: (a) critical attributes can be embedded in the RJP, leading to applicants' self- 
reflection on their own competencies and PV fit, (b) applicants are given accurate portrayals of the teaching environment which can help ready them for the classroom, reducing the potential for 'reality shock', and (c) they can self-select out before training begins if the PV fit is deemed to be poor. The DfE and Teach First both referenced versions of RJPs to attract applicants, although these were not found at the core of their recruitment messages. The DfE's recruitment strategy noted the Discover Teaching opportunities for applicants to experience teaching, including an expanded teaching internship programme, increasing availability of school taster days, and a new virtual reality classroom. The Teach First advertising brochure noted two programmes--Insight and Taster Experience--that provided potential applicants with brief teaching-related experiences. These 'taster' programmes provide potential applicants with a chance to assess their PV fit before committing to training, but research evidencing the scope and effectiveness of these programmes is needed.

New research on 'near-world' classroom scenarios. Web-based versions of RJPs represent a cost-effective way to deliver evidence-supported recruitment interventions at scale. Research by $<<$ the authors $>>$ is currently designing and testing the administration of interactive realistic classroom scenarios using a scenario-based learning format associated with 'near-world' learning models (e.g., Errington, 2011). In this recruitment intervention potential applicants are sent a series of animated classroom scenarios with instructions to view the scenarios, place themselves in the role of new classroom teacher, and rate the appropriateness of a range of response options. After recording their responses, real-time feedback provides information about the alignment of their responses with responses from experienced teachers, leading to a realistic view of the profession which may serve to attract applicants whose attributes fit well with the demands of the profession.

\section{A Model for Attribute-Based Recruitment and Selection}

Teacher recruitment strategies would benefit from methods reflecting the fit between applicants and the attributes needed for success in teaching. In Figure 4 we present a model (adapted from Ostroff \& Zhan, 2012) that integrates applicant and organisation perspectives in a PV fit-influenced teacher recruitment process. At the heart of this integrated approach is the identification of a set of agreed-upon attributes (highlighted in bold box) that are considered as critical for success in the profession, and that may vary according to context. Following Kunter's professional competence model, we include non-cognitive attributes such as personal attributes, beliefs, values alongside cognitive attributes like subject area knowledge, pedagogical content knowledge, and academic achievement (Kunter, Kleickmann, Klusmann, \& Richter, 2013). The desired attributes influence an organisation's teacher recruitment strategies, but they also influence the methods developed for selection, and later on, for professional development. During the recruitment process the key attributes 
influence an organisation's strategy and the content of messages delivered to the public.

During selection, the attributes inform screening and selection methods; the decision-making process is focused on weighing the fit between an applicant's characteristics and organisational key attributes. Finally, the desired attributes play a role in influencing the content of post-selection development activities.

Figure 4 here

From the applicants' perspective, the agreed-upon attributes play a role in influencing self-assessment through an analysis of existing beliefs about teaching and through analysis of recruitment messages encountered. Recruitment messages also influence applicants' anticipatory PV fit (I think I'm a good fit for this job) and consideration of teaching as a career. Applicants make decisions about entering teacher training programmes based on their evaluation of their own PV fit during the attraction and recruitment phase, and also during the selection phase when applicants assess their fit against the attributes highlighted in an organisation's selection activities. During initial teacher training, the applicant weighs their anticipatory fit against their experienced fit, influencing decisions about staying or leaving the profession (I didn't think teaching would be like this; I don't think I'm cut out for this). Thus an organisation's recruitment strategy and public-facing messages are important, not only for attracting and recruiting applicants, but as a foundation for recruiting, selecting, and developing applicants that fit well in the profession, and are more likely to stay and thrive in a teaching career.

\section{Teacher Recruitment: A Way Forward}

Based on our review of current teacher recruitment strategies and messages, and from research in related fields, we propose four courses of action to improve teacher recruitment:

\section{Build teacher attraction and recruitment strategies on a foundation of key} attributes

The NHS value based framework is an example of how identifying a set of key attributes can inform subsequent recruitment, selection, and professional development activities. Other fields, too, such as the College of Policing have used this approach to provide a conceptual framework on which to build human resources activities. Identifying a core set of agreed values is, without doubt, a daunting exercise. Questions quickly arise about the universality of attributes across settings, the relative importance of attributes, and the changing nature of desirable attributes through career stages. At the same time, the exercise to identify key attributes can focus an organisation on its mission, values, and beliefs that informs its mission. For initial guidance, there are numerous possible models that have been proposed that outline key teaching attributes, such as Kunter et al.'s competency model (e.g., Kunter et al., 2013) or the teaching attributes identified across cultures in Klassen et al., 2018. 


\section{Evaluate the effectiveness of current recruitment strategies}

Considerable effort and expense have been directed to develop recruitment strategies, but there is almost no research — in field or laboratory settings - that evaluates the effectiveness of these efforts. It is feasible that attraction strategies that focus on the social utility of teaching (Teachers make a difference!) and personal utility (through provision of incentives for training) will result in higher attrition than strategies focused on the fit between potential applicants and the demands of the job. Evaluating the effectiveness of current and future teacher recruitment strategies is a necessary step when considering how to improve the recruitment process.

\section{Learn from research in other fields}

In organisational psychology, recruitment and selection has been labelled as the supreme problem facing the field (Ployhart, Schmitt, \& Tippins, 2017) with over 100 years of research dedicated to solving the problem, and yet in education, where teacher shortages have been described as 'alarming', 'disastrous', and a 'catastrophe' (See \& Gorard, 2019), almost no attention has been paid to how to more effectively recruit (and select) prospective teachers. There are context-specific teacher recruitment challenges that require 'insider' knowledge, but education researchers and policy-makers will benefit from paying close attention to the theories and research in disciplines that have addressed these issues for more than a century. Teacher recruitment efforts can benefit from research and development activities that breach disciplinary silos, with potential benefits in cross-disciplinary collaborations.

\section{Explore innovative attraction and recruitment methods that can be delivered at} scale

Technological developments, especially capitalising on the ubiquity of personal devices, means that we are better equipped than ever before to deliver recruitment interventions to potential teacher applicants. We now have the technological means to move from broad social and personal utility messages to personally-tailored fit messages relatively cheaply to large groups of potential applicants. Teacher recruitment will always benefit from a range of methods, but we can now deliver tailored PV fit messages with feedback to attract potential applicants who may not previously have considered teaching as a career.

\section{Limitations and Conclusions}

Despite a systematic approach to reviewing recruitment theory, research, and practice, this article has several limitations. We included teacher recruitment strategies and messages from only two organisations - the DfE and Teach First - and although these are key players in teacher training in England, there are many other ITT programmes that make less wellresourced efforts to attract and recruit prospective teachers. We also focused only on England as a case study, and important work on improving teacher recruitment strategies is happening 
internationally. We used a specific lens from theories in educational and organisational psychology to analyse the recruitment documents, and lenses from other disciplines would have produced a different view of the content portrayed in the source documents. However, there is limited research on teacher recruitment strategies, and our deductive approach to analysing the materials provides a first step in discussing the kinds of messages portrayed by two important organisations involved in the recruitment of prospective teachers.

Identifying key teacher attributes is the first step to build the foundation of an integrated teacher recruitment, selection, and development framework. Current teacher recruitment strategies are well-meaning and very likely play a role in attracting new teachers, but little is known about their effectiveness, and there has been only modest attention paid to important theories and research from sources outside of education. Without theory-informed experimental and longitudinal field-tested research on teacher recruitment, we have very little idea about how current and prospective interventions actually work, and how we might construct more effective recruitment strategies. We look forward to seeing educational researchers working to develop and test new teacher recruitment strategies, and to work together with key education organisations to build a sustainable high-quality teacher workforce. 


\section{References}

Bardach, L., \& Klassen, R. M. (2020). Smart teachers, successful students? A systematic review of the literature on teachers' cognitive abilities and teacher effectiveness.

Educational Research Review, doi.org/10.1016/j.edurev.2020.100312

Baur, J. E., Buckley, M. R., Bagdasarov, Z., \& Dharmasiri, A. S. (2014). A historical approach to realistic job previews: An exploration into their origins, evolution, and recommendations for the future. Journal of Management History, 20, 200-223.

Bowen, G. A. (2009). Document analysis as a qualitative research method. Qualitative Research Journal, 9, 27-40.

Carr, J. (2020). Is the DfE's teaching ad spend paying off? Schools Week. Retrieved from https://schoolsweek.co.uk/is-the-dfes-teaching-ad-spend-paying-off/

College of Policing (2018). Values-based recruitment and selection. College of Policing Limited. Retrieved from https://www.college.police.uk/What-wedo/Development/competency-and-values-framework/Documents/ValuesBased_Recruitment_Guidance.pdf

Darrow, J. B., \& Behrend, T. S. (2017). Person-environment fit is a formative construct. Journal of Vocational Behavior, 103, 117-131.

De Cooman, R., De Gieter, S., Pepermans, R., Hermans, S., Du Bois, C., Caers, R., \& Jegers, M. (2009). Person-organization fit: Testing socialization and attraction-selection-attrition hypotheses. Journal of Vocational Behavior, 74(1), 102-107.

Department for Education (2019). Teacher recruitment and retention strategy. Retrieved from https://assets.publishing.service.gov.uk/government/uploads/system/uploads/attachment_d ata/file/786856/DFE_Teacher_Retention_Strategy_Report.pdf

Department for Education (2018). Areas of research interest. Retrieved from https://www.gov.uk/government/publications/department-for-education-areas-of-researchinterest

Errington, E. P. (2011). Mission possible: Using near-world scenarios to prepare graduates for the professions. Journal of Teaching and Learning in Higher Education, 23, 84-91.

Foster, D. (2019). Teacher recruitment and retention in England. House of Commons Briefing Paper 7222.

Garcia, E. \& Weiss, E. (2019). The teacher shortage is real, large and growing, and worse than we thought. Economic Policy Institute. Retrieved from https://www.epi.org/files/pdf/163651.pdf

Geiger, T., \& Pivovarova, M. (2018). The effects of working conditions on teacher retention. Teachers and Teaching, 24, 604-625. 
Hecht, C. A., Harackiewicz, J. M., Priniski, S. J., Canning, E. A., Tibbetts, Y., \& Hyde, J. S. (2019, April 4). Promoting Persistence in the Biological and Medical Sciences: An Expectancy-Value Approach to Intervention. Journal of Educational Psychology. Advance online publication. http://dx.doi.org/10.1037/edu0000356

Klassen, R. M., Durksen, T. L., Al Hashmi, W., Kim, L. E., Longden, K., Metsäpelto, R.-L., Poikkeus, A. M., \& Györi, J. (2018). Cultural context and teacher characteristics: Exploring the non-cognitive attributes of prospective teachers in four countries. Teaching and Teacher Education, 72, 64-74.

Kunter, M., Kleickmann, T., Klusmann, U., \& Richter, D. (2013). The development of teachers' professional competence. In M. Kunter, J. Baumert, W. Blum, U. Klusmann, S. Krauss, \& M. Neubrand (Eds.), Cognitive activation in the mathematics classroom and professional competence of teachers (pp. 63-77). Springer: New York.

Miller, S. \& Bird, J. (2014). Assessment of practitioners' and students' values when recruiting. Nursing Management, 21, 22-29.

NHS (2020). Recruitment based on the NHS Constitution. Retrieved from https://www.hee.nhs.uk/our-work/values-based-recruitment

NHS (2016). Values Based Recruitment Framework. Health Education England. Retrieved from https://www.hee.nhs.uk/sites/default/files/documents/VBR_Framework\%20March\%20201 $\underline{6 . p d f}$

OECD (2018). Effective teacher policies: Insights from PISA. OECD Publishing. Retrieved from http://dx.doi.org/10.1787/9789264301603-en

Ostroff, C., \& Zhan, Y. (2012). Person-environment fit in the selection process. In N. Schmitt (Ed.), The Oxford handbook of personnel assessment and selection (pp. 252-273). Oxford: Oxford University Press.

Parks, L. \& Guay, R. P. (2009). Personality, values, and motivation. Personality and Individual Differences, 47, 675-684.

Ployhart, R. E., Schmitt, N., \& Tippins, N. T. (2017). Solving the Supreme Problem: 100 years of selection and recruitment at the Journal of Applied Psychology. Journal of Applied Psychology, 102, 291-304.

Podolsky, A., Kini, T., Darling-Hammond, L. \& Bishop, J. (2019). Strategies for attracting and retaining educators: What does the evidence say? Education Policy Analysis Archives, 27, $1-43$.

Richardson, P. W., \& Watt, H. M. (2016). Factors influencing teaching choice: Why do future teachers choose the career?. In International handbook of teacher education (pp. 275-304). Springer, Singapore. 
Roberson, Q. M., Collins, C. J., \& Oreg, S. (2005). The effects of recruitment message specificity on applicant attraction to organizations. Journal of Business and Psychology, 19, 319-339.

See, B. H., \& Gorard, S. (2019). Why don't we have enough teachers? A reconsideration of the available evidence. Research Papers in Education, DOI:

$10.1080 / 02671522.2019 .1568535$

See, B. H., Gorard, S., Morris, R., \& El Soufi, N. (2019). Attracting and retaining teachers in hard to staff areas: What does the evidence say? Durham University Evidence Centre for Education. Retrieved from https://www.dur.ac.uk/dece/

Sundorph, E. (2018). Britain at a crossroads: what will it take to provide the teachers our children need? Teach First. Retrieved from https://www.teachfirst.org.uk/sites/default/files/2019-08/britain_at_a_crossroads_2.pdf

Uggerslev, K. L., Fassina, N. E., \& Kraichy, D. (2012). Recruiting through the stages: A meta-analytic test of predictors of applicant attraction at different stages of the recruiting process. Personnel Psychology, 65, 597-660.

UNESCO (2016). The world needs almost 69 million new teachers to reach the 2030 education goals. Retrieved from https://unesdoc.unesco.org/ark:/48223/pf0000246124

Vogel, R. M. \& Feldman, D. C. (2009). Integrating the levels of person-environment fit: The roles of vocational fit and group fit. Journal of Vocational Behavior, 75, 68-81.

Watt, H. M., \& Richardson, P. W. (2008). Motivations, perceptions, and aspirations concerning teaching as a career for different types of beginning teachers. Learning and Instruction, 18(5), 408-428.

Watt, H. M., \& Richardson, P. W. (2007). Motivational factors influencing teaching as a career choice: Development and validation of the FIT-Choice scale. The Journal of Experimental Education, 75(3), 167-202. 


\section{Figure 1}

Simple Model of Teacher Attraction and Recruitment

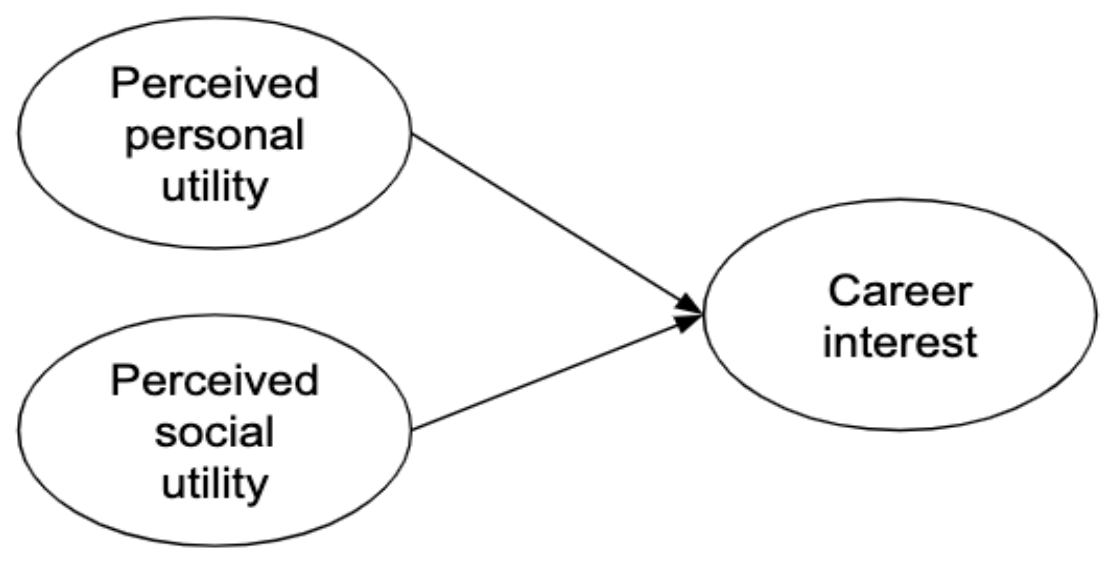

\section{Figure 2}

Mediated Model of Teacher Attraction and Recruitment

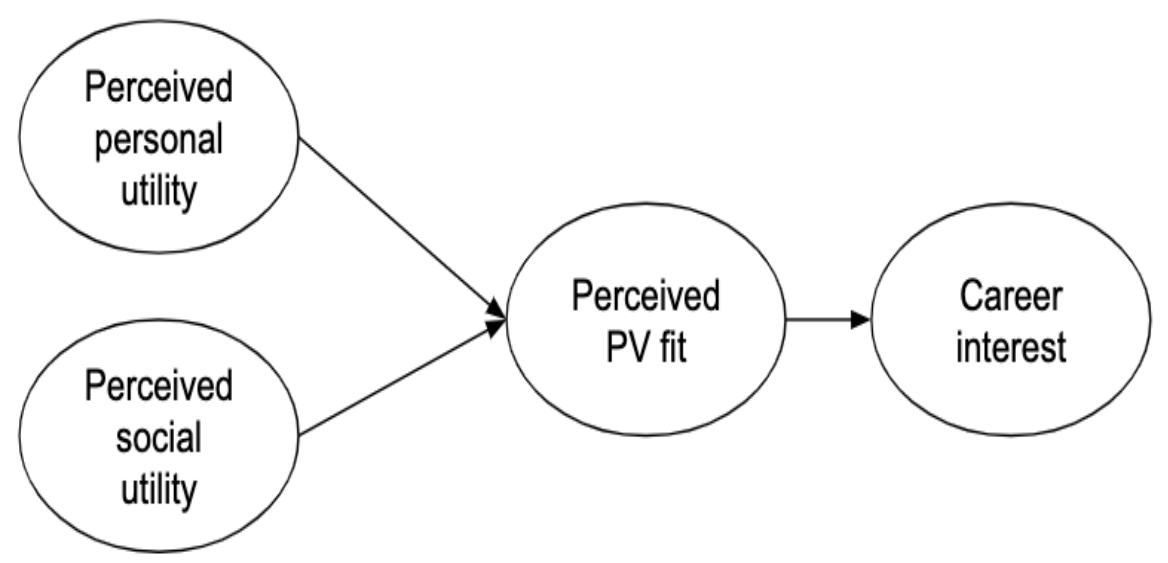


$100 \%$

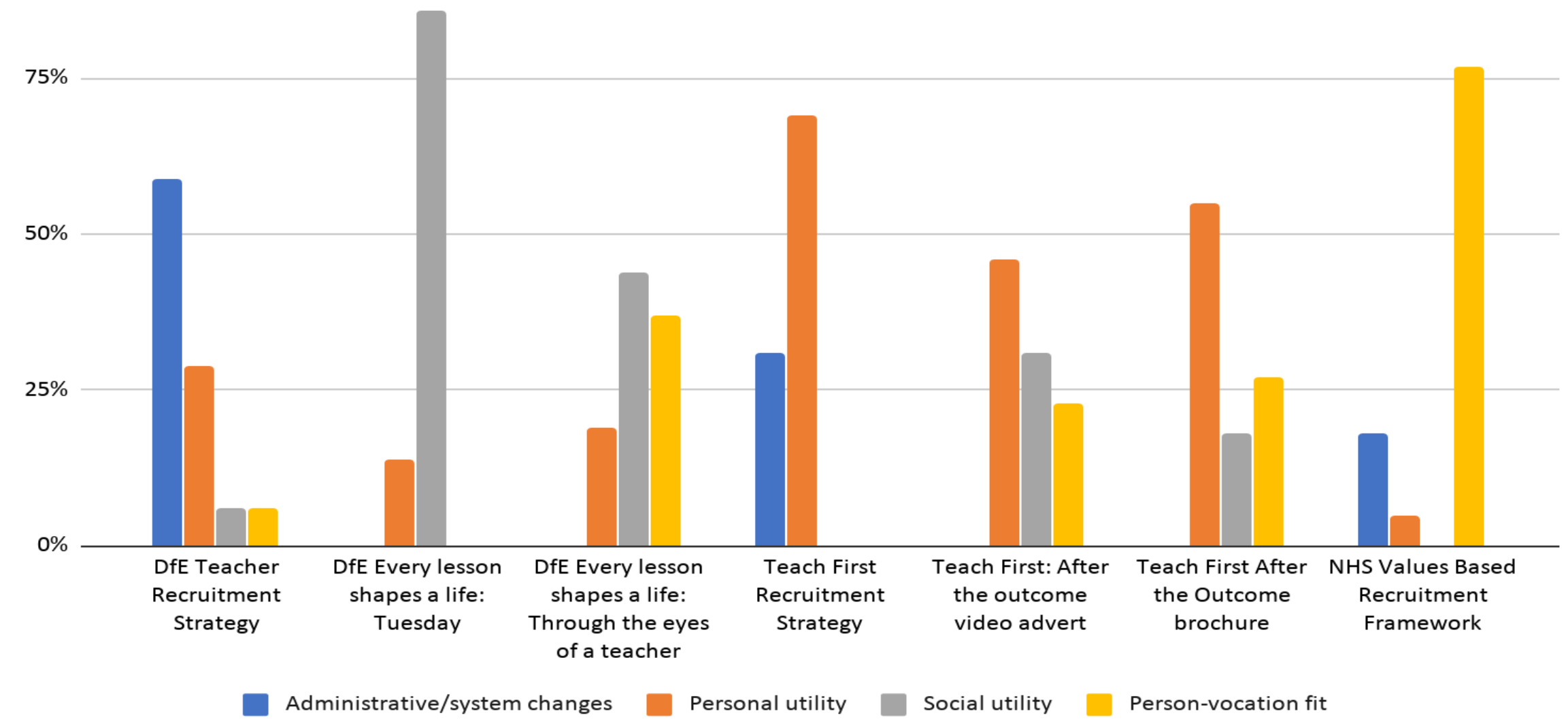

Figure 3

Recruitment Messages in Strategy Documents and Advertisements 


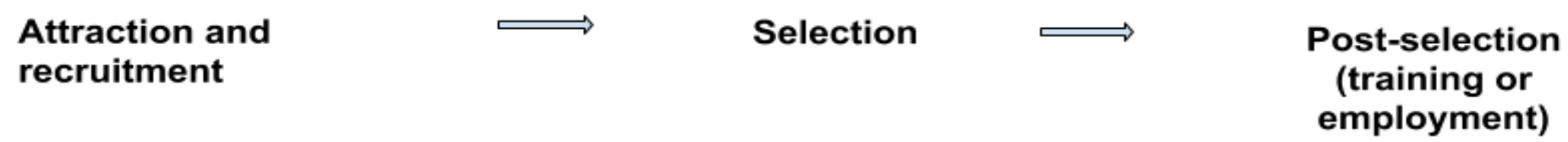

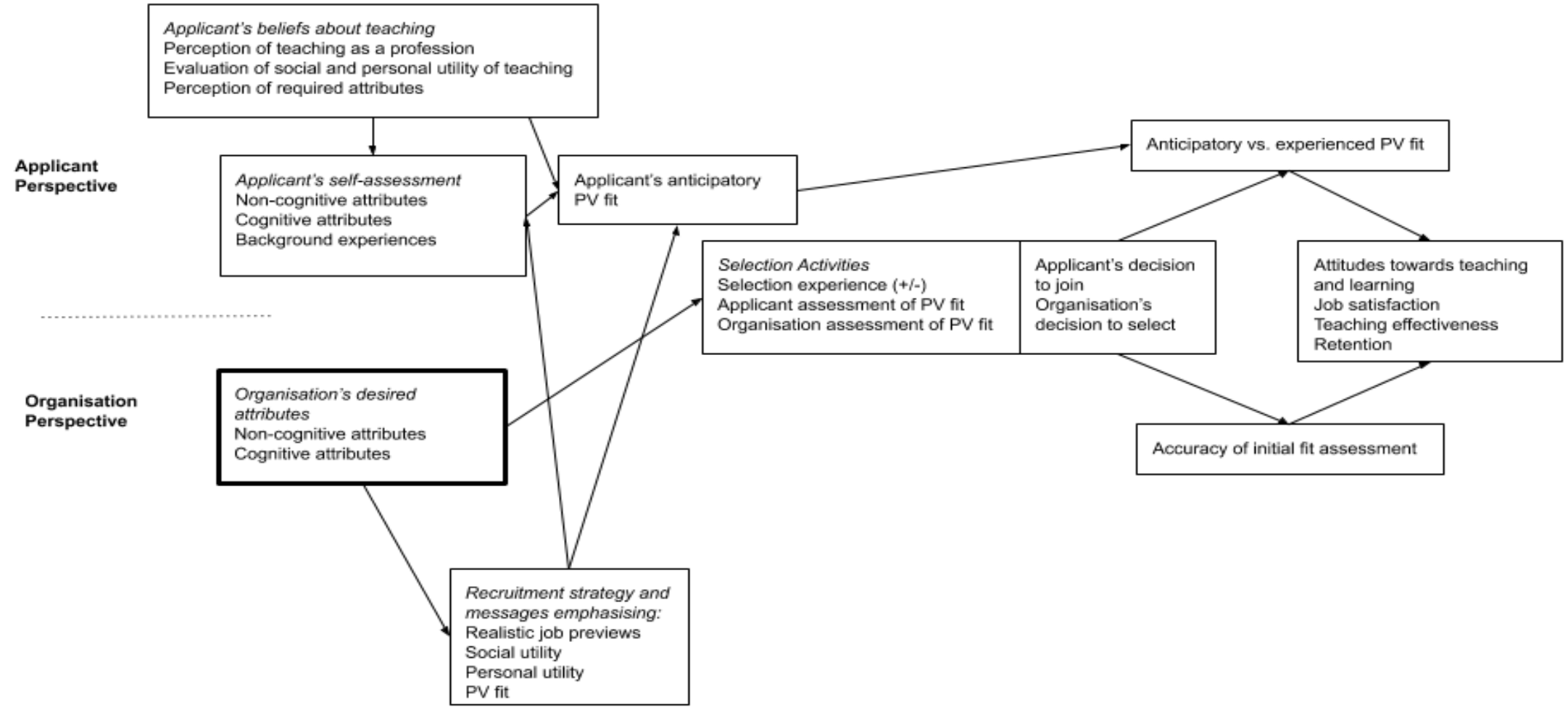

Figure 4

Applicant and Organisation Perspectives on Fit in Recruitment and Selection 


\section{Appendix A}

Framework for Description and Categorisation

\begin{tabular}{|c|c|}
\hline Category & Code \\
\hline $\begin{array}{l}\text { Administrative/system changes: Attract } \\
\text { applicants by improving application process } \\
\text { and options }\end{array}$ & $\mathrm{AC}$ \\
\hline - Change eligibility policies & AEP \\
\hline - Change application process & AA \\
\hline - New routes into teaching & ART \\
\hline $\begin{array}{l}\text { Personal Utility: Attract applicants by offering } \\
\text { personal benefits }\end{array}$ & PU \\
\hline - General financial investment & PGI \\
\hline - Salary & PS \\
\hline - Incentives for training & PIT \\
\hline - Incentives in post & PIP \\
\hline - Working conditions & PWC \\
\hline - Career progression & PCP \\
\hline - Other personal benefit & POB \\
\hline $\begin{array}{l}\text { Social Utility: Attract applicants by showing } \\
\text { benefits to society }\end{array}$ & SU \\
\hline $\begin{array}{l}\text { - Influence social-emotional lives of } \\
\text { children }\end{array}$ & $\mathrm{SC}$ \\
\hline - Influence learning & SL \\
\hline - Influence children's lives generally & SG \\
\hline $\begin{array}{l}\text { PV fit: References to assessing the fit between } \\
\text { applicants and teaching }\end{array}$ & FIT \\
\hline - Job previews & FJP \\
\hline $\begin{array}{l}\text { - Highlighting attributes (values and } \\
\text { competencies) }\end{array}$ & FRA \\
\hline
\end{tabular}




\section{Appendix B}

Frequency table: Analysis of Attraction and Recruitment Policies and Public-Facing Content in Three Contexts

\begin{tabular}{|c|c|c|c|}
\hline Source & Description of recruitment activity & & Coding of recruitment activity \\
\hline \multirow{8}{*}{$\begin{array}{l}\text { DfE Teacher } \\
\text { Recruitment } \\
\text { and Retention } \\
\text { Strategy (2019) }\end{array}$} & $\begin{array}{l}\text { Strategy document released in } 2019 \text { that highlights key barriers } \\
\text { and strategy priorities to increase teacher retention and to } \\
\text { improve teacher recruitment processes }\end{array}$ & & \\
\hline & Establish supportive school culture to attract staff & p.6 & PWC \\
\hline & 'Local offer' packages to increase teacher recruitment & P. 17 & PIP \\
\hline & $\begin{array}{l}\text { Currently we spend around } £ 250 \text { million a year attracting high } \\
\text { quality graduates...with tax-free bursaries of up to } £ 26,000 \text { and } \\
\text { other financial incentives... which play a key role in attracting } \\
\text { more people into teaching }\end{array}$ & p. 22 & PIT \\
\hline & Flexible working should attract more people to join teaching & P. 28 & PWC \\
\hline & $\begin{array}{l}\text { Our latest campaign 'Every Lesson Shapes a Life' highlights how } \\
\text { teachers change and shape the lives of their pupils each and every } \\
\text { day }\end{array}$ & P. 32 & $\mathrm{SC}$ \\
\hline & $\begin{array}{l}\text { Discover Teaching will provide a new breadth of opportunities } \\
\text { for people to experience teaching, including a new virtual reality } \\
\text { classroom, expanding the Teaching Internship Programme, and } \\
\text { increasing school taster days }\end{array}$ & P. 32 & FJP \\
\hline & $\begin{array}{l}\text { That is why we will use digital technologies to bring the } \\
\text { application process into the } 21 \text { st century, improving the applicant }\end{array}$ & P. 32 & AA \\
\hline
\end{tabular}




\begin{tabular}{|c|c|c|}
\hline experience at every stage of the journey to becoming a teacher & & \\
\hline $\begin{array}{l}\text { Radically simplify the process of applying to be a teacher, } \\
\text { making it quicker and allowing greater flexibility for applicants }\end{array}$ & P. 32 & AA \\
\hline $\begin{array}{l}\text { Provide personalised support to help individual applicants at each } \\
\text { crucial stage in the user journey }\end{array}$ & p.33 & AA \\
\hline $\begin{array}{l}\text { We have recruited experienced teachers... to provide bespoke } \\
\text { support and advice to applicants all the way through their } \\
\text { application }\end{array}$ & p.33 & AA \\
\hline $\begin{array}{l}\text { We have invested in a state of the art customer relationship } \\
\text { management system providing personalised advice and support to } \\
\text { all applicants }\end{array}$ & p.33 & AA \\
\hline $\begin{array}{l}\text { Investing over } £ 6 \text { million on a range of initiatives to attract up to } \\
1.1 \text { million people over the age of } 25 \text { who would consider } \\
\text { teaching }\end{array}$ & p.33 & ART \\
\hline Develop a bespoke route for career changers & p.33 & ART \\
\hline $\begin{array}{l}\text { Expanding the reach of Now Teach to new areas and supporting a } \\
\text { new Transition to Teach initiative }\end{array}$ & p.33 & ART \\
\hline $\begin{array}{l}\text { Consider extending the teacher occupations that are on the } \\
\text { Shortage Occupation list }\end{array}$ & p.33 & ART \\
\hline $\begin{array}{l}\text { Work closely with universities and schools to explore how they } \\
\text { can support more teaching assistants to choose to teach }\end{array}$ & p.33 & ART \\
\hline $\begin{array}{l}\text { Ensure the right incentives exist to support strong trainees to } \\
\text { work where they are needed most }\end{array}$ & P. 34 & PIP \\
\hline
\end{tabular}




\begin{tabular}{|c|c|c|}
\hline \multirow{8}{*}{$\begin{array}{l}\text { DfE: Every } \\
\text { lesson shapes a } \\
\text { life - Tuesday ( } \\
\text { 2020) }\end{array}$} & $\begin{array}{l}\text { Portrays daily activities of secondary science teacher: greeting } \\
\text { pupils, interactions with pupils, teaching lessons }\end{array}$ & \\
\hline & Teacher explains concept & SL \\
\hline & Interacts with pupil outside & $\mathrm{SC}$ \\
\hline & Interacts with peers & PWC \\
\hline & Helps troubled pupil & $\mathrm{SC}$ \\
\hline & Disciplines pupil - it stops right now & $\mathrm{SC}$ \\
\hline & End of day reflection & SL \\
\hline & Positive interaction with pupil & $\mathrm{SC}$ \\
\hline \multirow{5}{*}{$\begin{array}{l}\text { DfE: Every } \\
\text { lesson shapes a } \\
\text { life - Through } \\
\text { the eyes of a } \\
\text { teacher (2019) }\end{array}$} & $\begin{array}{l}\text { Accounts from multiple teachers and students about the } \\
\text { challenges and rewards of the job }\end{array}$ & \\
\hline & The little moments you have with students & $\mathrm{SC}$ \\
\hline & Seeing the change in students over long period of time & SL \\
\hline & You can have a positive impact on a child relatively quickly & $\mathrm{SC}$ \\
\hline & Students: She's really energetic all of the time & FRA \\
\hline
\end{tabular}




\begin{tabular}{|c|c|c|}
\hline & $\begin{array}{l}\text { Students: She understands us ; she helps us with the work; she } \\
\text { makes it fun }\end{array}$ & FRA \\
\hline & $\begin{array}{l}\text { The variety is unmatched - watching a child succeed and } \\
\text { knowing you've been part of the process The reward you get } \\
\text { from that is unlike anything I've done before }\end{array}$ & SG \\
\hline & Teaching is demanding; but highly rewarding & FJP \\
\hline & I come to school and know I'm making a difference & SG \\
\hline & $\begin{array}{l}\text { My biggest impact is in introducing students to the world outside } \\
\text { of school }\end{array}$ & SG \\
\hline & $\begin{array}{l}\text { A good teacher should engage with students so that they can } \\
\text { become better people, not just better students in the future }\end{array}$ & FRA \\
\hline & $\begin{array}{l}\text { I'm known as the 'strict teacher'.. But I do it because I care about } \\
\text { you. I'm not just an English teacher, I'm also here to change lives }\end{array}$ & SU \\
\hline & $\begin{array}{l}\text { A day in the life of a teacher is very intense, but there are huge } \\
\text { rewards }\end{array}$ & FJP \\
\hline & By far the most rewarding job I've ever done & POB \\
\hline & No two days are the same & PWC \\
\hline & I've never been bored in this job, ever & PWC \\
\hline & Be ready for anything to happen & FRA \\
\hline $\begin{array}{l}\text { Teach First } \\
\text { Britain at a } \\
\text { crossroads }\end{array}$ & $\begin{array}{l}\text { Strategy document introducing new recruitment and development } \\
\text { strategy }\end{array}$ & \\
\hline
\end{tabular}




\begin{tabular}{|c|c|c|c|}
\hline \multicolumn{3}{|l|}{ (2018) } & \\
\hline & $\begin{array}{l}\text { Workload is the first topic in any discussion about the } \\
\text { attractiveness of teaching in the UK }\end{array}$ & P. 6 & PWC \\
\hline & $\begin{array}{l}\text { Increased flexible working options could allow more teachers to } \\
\text { return }\end{array}$ & p.7 & PWC \\
\hline & $\begin{array}{l}\text { If teaching is to remain attractive to future generations... } \\
\text { solutions to ensure flexible working must be found }\end{array}$ & p.9 & PWC \\
\hline & $\begin{array}{l}\text { But to attract new recruits and ensure people are able to stay, the } \\
\text { (pay) deal for teachers has to improve }\end{array}$ & P.9 & PS \\
\hline & $\begin{array}{l}\text { To improve recruitment and retention of teachers, pay must } \\
\text { compare favourably with similar professions - both in terms of } \\
\text { starting salaries and as teachers progress }\end{array}$ & P. 9 & PS \\
\hline & $\begin{array}{l}\text { Financial incentives are believed (by headteachers) to be } \\
\text { particularly effective when recruiting teachers }\end{array}$ & P. 9 & PIP \\
\hline & $\begin{array}{l}\text { Increasing the pay of unqualified teachers may be a particularly } \\
\text { important factor in attracting more career changers to the } \\
\text { profession }\end{array}$ & P. 10 & PIT \\
\hline & $\begin{array}{l}\text { To attract more people into teaching, the Government has so far } \\
\text { implemented a range of bursaries, particularly in shortage } \\
\text { subjects. It's not yet clear to what extent these have had a positive } \\
\text { effect. }\end{array}$ & P. 10 & PIT \\
\hline & $\begin{array}{l}\text { It's a sobering evaluation when exploring if returning qualified } \\
\text { teachers can be a solution to the teacher shortage. It suggests that } \\
\text { efforts may need to be tailored to both the individual and the }\end{array}$ & p.11 & ART \\
\hline
\end{tabular}




\begin{tabular}{|c|c|c|c|}
\hline & school in question. & & \\
\hline & $\begin{array}{l}\text { With the right approach, even more people could be persuaded to } \\
\text { change careers into teaching }\end{array}$ & P. 12 & ART \\
\hline & $\begin{array}{l}\text { We have launched a Teaching Assistant Fast Track route onto our } \\
\text { programme }\end{array}$ & p.12 & ART \\
\hline & $\begin{array}{l}\text { A loss of income, or the potential cost of training, is one of the } \\
\text { main barriers to changing careers into teaching }\end{array}$ & P. 12 & $\begin{array}{l}\text { ART } \\
\text { PIT }\end{array}$ \\
\hline $\begin{array}{l}\text { Teach First } \\
\text { Alter the } \\
\text { outcome video } \\
\text { (2019) }\end{array}$ & $\begin{array}{l}\text { Interviews with teachers in school contexts at various career } \\
\text { stages }\end{array}$ & & $\begin{array}{l}\text { Personal utility: career progression } \\
\text { opportunities; you're doing something that } \\
\text { truly aligned to what makes you happy, you } \\
\text { can only do that when you have an impact on } \\
\text { other people's lives; What kind of career is } \\
\text { going to stimulate me? It'll be the most } \\
\text { challenging thing you've ever done, } \\
\text { Social utility: influencing the outcomes of } \\
\text { children from disadvantaged backgrounds; } \\
\text { Let's give opportunities to kids who wouldn't } \\
\text { normally have those opportunities } \\
\text { Person-vocation fit: I was looking for two key } \\
\text { elements: challenge and opportunities; If } \\
\text { you've got the ambition, then the opportunities } \\
\text { for progression are endless; }\end{array}$ \\
\hline & $\begin{array}{l}\text { I initially went into finance but didn't feel like I was making the } \\
\text { difference I set out to make }\end{array}$ & & SG \\
\hline & The most important thing is to be true to yourself and to be happy & & PU \\
\hline
\end{tabular}




\begin{tabular}{|c|c|}
\hline with what you're doing day to day & \\
\hline $\begin{array}{l}\text { I was looking around and thinking what kind of career is going to } \\
\text { stimulate me }\end{array}$ & POB \\
\hline I was looking for two key elements: challenge and opportunity & FRA \\
\hline $\begin{array}{l}\text { Let's give opportunities to kids that wouldn't normally have these } \\
\text { opportunities }\end{array}$ & SG \\
\hline $\begin{array}{l}\text { The truly remarkable thing about education is what a wonderful } \\
\text { gift you've been given - a parent has taken the most valuable } \\
\text { thing in their life and handed them to you }\end{array}$ & SG \\
\hline I'm really proud of what I do every day & PU \\
\hline $\begin{array}{l}\text { In terms of the career progression I've had and the experience } \\
\text { I've had it's been a superb choice }\end{array}$ & PCP \\
\hline Even now as a HT, I'm constantly being supported & $\mathrm{PWC}$ \\
\hline $\begin{array}{l}\text { If you've got the ambition, then the opportunities for progression } \\
\text { are endless }\end{array}$ & FRA \\
\hline It'll be the most challenging thing you've ever done & FRA \\
\hline $\begin{array}{l}\text { But you'll be able to look at yourself in the mirror and say yeah } \\
\text { I've done something really worthwhile }\end{array}$ & PU \\
\hline $\begin{array}{l}\text { You're doing something truly aligned to what makes you happy. I } \\
\text { think you can only get that when you're having an impact on } \\
\text { other people's lives }\end{array}$ & SU \\
\hline
\end{tabular}




\begin{tabular}{|c|c|c|c|}
\hline \multirow{9}{*}{$\begin{array}{l}\text { Teach First } \\
\text { Alter the } \\
\text { outcome: A job } \\
\text { where you're... } \\
\text { brochure } \\
\text { (2019) }\end{array}$} & $\begin{array}{l}\text { Advertising brochure distributed to universities for attracting } \\
\text { potential Teach First participants }\end{array}$ & & \\
\hline & Earn a salary on day one in the classroom & p.6 & PIT \\
\hline & Train on a programme rated 'Outstanding' by Ofsted & p.6 & POB \\
\hline & Gain a fully-funded PGDE & p.6 & POB \\
\hline & Help children in schools that need you most & p.6 & $\mathrm{SC}$ \\
\hline & $\begin{array}{l}\text { Develop skills and accredited leadership that will propel your } \\
\text { career }\end{array}$ & p.6 & POB \\
\hline & Pursue a master's qualification at a reduced cost & p.6 & POB \\
\hline & Receive dedicated support from three sources & p.6 & POB \\
\hline & $\begin{array}{l}\text { Here's what we look for during our application: } \\
\text { - Effective interaction } \\
\text { - Humility, respect, and empathy } \\
\text { - Leadership } \\
\text { - Planning and organisation } \\
\text { - Problem-solving } \\
\text { - Resilience } \\
\text { - Self-evaluation } \\
\text { - Understanding and motivation }\end{array}$ & P. 7 & FRA \\
\hline
\end{tabular}




\begin{tabular}{|c|c|c|c|}
\hline & $\begin{array}{l}\text { Choose to teach A. and make a difference. B. And make a } \\
\text { difference where you're needed most }\end{array}$ & P. 10 & $\mathrm{SC}$ \\
\hline & $\begin{array}{l}\text { Our Insights for students are a chance to gain real classroom } \\
\text { experience and leadership skills before graduation }\end{array}$ & p.20 & FJP \\
\hline & $\begin{array}{l}\text { Try teaching with our Taster Experience. These two-day courses } \\
\text { are an excellent way for university students to learn more about } \\
\text { Teach First and discover whether teaching is right for you }\end{array}$ & p. 20 & FJP \\
\hline \multirow{5}{*}{$\begin{array}{l}\text { NHS Values } \\
\text { Based } \\
\text { Recruitment } \\
\text { Framework } \\
(2016)\end{array}$} & $\begin{array}{l}\text { Strategy document outlining Values Based Recruitment processes } \\
\text { to recruiting and selecting 'the right workforce with the right } \\
\text { skills in the right numbers with the right values' }\end{array}$ & & \\
\hline & $\begin{array}{l}\text { All Higher Education Institutions delivering NHS funded training } \\
\text { programmes are required to assess students for the values using } \\
\text { the core requirements set out in this framework. This takes place } \\
\text { as part of existing recruitment processes which assess aptitude } \\
\text { and skills. }\end{array}$ & P. 10 & FRA \\
\hline & $\begin{array}{l}\text { Employers are also encouraged to do the same in recruiting NHS } \\
\text { employees. }\end{array}$ & P. 10 & FRA \\
\hline & $\begin{array}{l}\text { Help those who train and employ NHS staff recruit people with } \\
\text { the right values }\end{array}$ & P. 10 & FRA \\
\hline & Help foster a values based environment & P. 10 & PWC \\
\hline
\end{tabular}




\begin{tabular}{|c|c|c|}
\hline $\begin{array}{l}\text { HEE will oversee delivery of a national values based recruitment } \\
\text { framework }\end{array}$ & P. 11 & FRA \\
\hline $\begin{array}{l}\text { Developing the right people with the right skills and the right } \\
\text { values }\end{array}$ & P. 11 & FRA \\
\hline $\begin{array}{l}\text { HEE must work with healthcare providers, regulators, and } \\
\text { educational institutions to ensure both recruitment processes and } \\
\text { training curricula consistently reinforce these values }\end{array}$ & P. 11 & $\mathrm{AC}$ \\
\hline $\begin{array}{l}\text { Building on the work already underway, HEE will work with } \\
\text { stakeholders, including employers, professional bodies and } \\
\text { education providers, to develop evidence-based approaches to } \\
\text { recruitment and selection for training based on values and } \\
\text { behaviours as well as technical and academic skills. }\end{array}$ & p.11 & $\mathrm{AC}$ \\
\hline $\begin{array}{l}\text { It is, therefore, important that all students on NHS funded } \\
\text { training programmes and all employees are recruited for values to } \\
\text { support and enhance a culture that delivers excellent patient care } \\
\text { and experience. }\end{array}$ & P. 13 & FRA \\
\hline $\begin{array}{l}\text { VBR is an approach which (alongside aptitude and skills) attracts } \\
\text { and selects students, trainees or employees on the basis that their } \\
\text { individual values and behaviours align with the values of the } \\
\text { NHS Constitution }\end{array}$ & p.14 & FRA \\
\hline $\begin{array}{l}\text { The purpose of HEE's VBR programme was to ensure that the } \\
\text { future and current NHS workforce is selected against the values } \\
\text { of the NHS constitution }\end{array}$ & P. 21 & FRA \\
\hline Fast-track leadership programmes & P. 27 & $\mathrm{AC}$ \\
\hline
\end{tabular}




\begin{tabular}{|c|c|c|}
\hline Pre-nursing care experience pilots & P. 27 & FJP \\
\hline $\begin{array}{l}\text { Values based recruitment into HEIs (all students on NHS funded } \\
\text { programmes are recruited for the values of the NHS) }\end{array}$ & P. 27 & FRA \\
\hline Values based recruitment into the NHS & P. 30 & FRA \\
\hline $\begin{array}{l}\text { Health careers detailed information about more than } 350 \text { roles. It } \\
\text { encourages potential employees to consider a career in health }\end{array}$ & P. 32 & $\mathrm{AC}$ \\
\hline $\begin{array}{l}\text { VBR toolkit for social care employers... to assist employers to } \\
\text { recruit on the basis of a set of appropriate values }\end{array}$ & P. 34 & FRA \\
\hline $\begin{array}{l}\text { Values should be detailed in the attraction material and } \\
\text { specifications for the position alongside key competencies and } \\
\text { attributes to support self-selection and value congruence }\end{array}$ & P. 52 & FRA \\
\hline $\begin{array}{l}\text { Personality measures may be useful at the attraction phases of } \\
\text { VBR as part of self-assessment for roles within the NHS or to } \\
\text { drive more focused questioning at interviews }\end{array}$ & P. 52 & FRA \\
\hline $\begin{array}{l}\text { With regard to VBR, as well as individual applicants having key } \\
\text { competencies and aptitudes, there needs to be a good fit between } \\
\text { an individual's personal values and those of the organisation } \\
\text { (value congruence). This is because when an individual's values } \\
\text { closely match those of the organisation, they report a significant } \\
\text { increase in job satisfaction and commitment to the organisation. }\end{array}$ & P. 52 & FRA \\
\hline $\begin{array}{l}\text { Although often values are not made explicit within recruitment } \\
\text { processes, recruitment systems can be designed to make this } \\
\text { more explicit both in attraction and also in the assessment }\end{array}$ & P. 52 & FRA \\
\hline
\end{tabular}




\begin{tabular}{|l|l|l|l|}
\hline & process. & & \\
\hline & $\begin{array}{l}\text { Most HEI programmes already include values as part of their } \\
\text { attraction strategy }\end{array}$ & P. 69 & FRA \\
\hline
\end{tabular}

